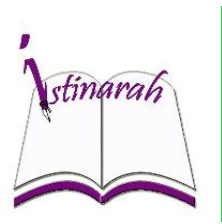

\title{
Study Living Qur'an terhadap Tradisi Pembacaan Al-Quran di Kuburan Pagi dan Petang Selama Tujuh Hari
}

\author{
Novia Permata Sari *) \\ Batusangkar, Tanah Datar \\ Sumatera Barat, Indonesia \\ E-mail: \\ noviap007@gmail.com
}

\section{Risman Bustamam}

Institut Agama Islam Negeri

Batusangkar, Sumatera Barat, Indonesia

E-mail:

rismanbustamam@yahoo.com

*) Corresponding Author

\begin{abstract}
The habit of the people of Nagari Balimbing reading Yasin's letter in the morning and evening at the cemetery for seven days is a special attraction. The focus of the research is on the history of the emergence of the tradition of reading Yasin in the morning and evening at the cemetery for seven days, then the practice of reading Yasin in the morning and evening at the cemetery for seven days and the meaning of reading Yasin in the morning and evening at the cemetery for seven days. The type of research that the author uses is a type of field research or (field research) using qualitative descriptive methods. This research data collection technique was obtained from the results of observations, interviews and documentation of researchers with the results of the study it was known that this tradition had been going on from generation to generation which is still being carried out, which originated from the Tariqa Syatariyah brought by Sheikh Burhanuddin from Ulakan. The practice of this tradition is carried out in the morning and evening at the cemetery for seven days in a row by the family of the corpse, namely by reading alfatihah, watering talqin, reciting prayers for the torment of the grave, surah yasin, surah al-ikhlas, al-falaq and an-nas.
\end{abstract}

Abstrak: Kebiasaan masyarakat Nagari Balimbing membaca AlQuran pagi dan petang di kuburan selama tujuh hari menjadi daya Tarik tersendiri. Fokus penelitian tentang sejarah munculnya tradisi pembacaan Surat Yasin pagi dan petang di kuburan selama tujuh hari kemudian praktek pembacaan Al-Quran pagi dan petang di kuburan selama tujuh hari serta makna pembacaan AlQuran pagi dan petang di kuburan selama tujuh hari. Jenis penelitian yang digunakan adalah penelitian lapangan atau (field research) dengan menggunakan metode deskriptif kualitatif. Data penelitian diperoleh dari hasil observasi, wawancara dan dokumentasi. Hasil menunjukkan bahwa tradisi ini telah berlangsung secara turun-temurun yang sampai saat ini tetap dilaksanakan. Berdasarlkan tela'ahan sumber data juga ditemukan informasi bahwa tradisi ini berasal dari Tarikat Syatariyah yang di bawa oleh Syekh Burhanuddin dari Ulakan. Praktek tradisi ini dilaksanakan pada pagi dan petang di kuburan selama tujuh hari berturut-turut oleh keluarga si mayat, yaitu dengan membacakan alfatihah,menyiram air talqin, membacakan doa siksa kubur, surah yâsin, surat al-ikhlas, al-falaq dan an-nas.

Kata Kunci: Tradisi, Yasin, Kuburan, Pagi dan Petang, Balimbing

\section{PENDAHULUAN}

Al-Qur an adalah kalam Allah Swt yang apabila membacanya mendapatkan pahala, sebagaimana disebutkan dalam surat Fathir/35: 2930

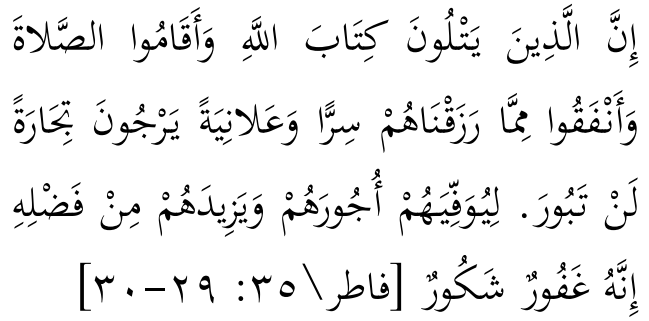


Artinya: Sesungguhnya orang-orang yang selalu membaca kitab Allah dan mendirikan salat dan menafkahkan sebahagian dari rezeki yang Kami anugerahkan kepada mereka dengan diam-diam dan terang-terangan, mereka itu mengharapkan perniagaan yang tidak akan merugi, agar Allah menyempurnakan kepada mereka pahala mereka dan menambah kepada mereka dari karunia-Nya. Sesungguhnya Allah Maha Pengampun lagi Maha Mensyukuri.

Membaca Al-Qur`an dapat dilakukan kapan dan dimana saja, baik sendiri maupun bersama-sama, asalkan tempatnya bersih dari hadast dan najis. Bahkan dalam masyarakat, membaca Al-Qur`an ada yang dijadikan sebuah tradisi, baik tradisi berupa adat istiadat maupun ritual keagamaan.

Al-Qur`an sebagai kitab suci umat Islam memuat hal-hal yang menarik, salah satunya adalah menekankan untuk menjalankan tata kehidupan yang selaras dengan Islam. Dengan mempelajari Al-Qur`an berdasarkan fenomenologi yang bertaut pada peristiwa satu dengan yang lain. Tata kehidupan yang dijalani oleh umat Islam memiliki kebenaran yang nyata di dalam Al-Qur`an apabila ingin menjalankan sesuai dengan syariat. Dengan manusia berusaha untuk mentradisikan mengkaji Al-Qur’an sebagai dasar bertindak diharapkan ada penghayatan yang baik mengenai esensi kehidupan. (Hadi Mutamam, 2015: 323). Dengan demikian, pemahaman Al-Qur`an yang kurang utuh karena belum mencerminkan satu kesatuan pemahaman terpadu dari ajaran Al-Qur’an yang fundamental, karena itu di perlukan sebuah pemahaman dan ritual pada Al-Qur`an yang dapat mencerminkan satu kesatuan pandangan yang utuh dan terpadu dari ajaran Al-Qur`an.( M. Amin Abdullah, 1996: 139)

Al-Qur’an membentuk ritual pada kehidupan umat Islam melalui rukun dan kewajiban sebagai manusia yang mempercayai agama. (Nata, 2010: 39). Sebenarnya, ritual dalam Islam memilki sejarah tersendiri. Sejarah atau historis adalah ilmu yang didalamnya dibahas berbagai peristiwa dengan memperhatikan unsur-unsur tempat, waktu, objek, latar belakang dan pelaku dari peristiwa tersebut. (Nata, 2010: 46)

Al-Qur`an dipahami secara terus menerus dapat membentuk kebudayaan. Didalam kebudayaan tersebut terdapat pengetahuan, keyakinan, seni, moral, adat istiadat dan sebagainya. Hal itu selanjutnya digunakan sebagai acuan oleh seseorang dalam menjawab berbagai masalah yang dihadapinya. Dengan demikian, Al-Qur`an dalam membentuk kebudayaan tampil sebagai pranata yang secara terus menerus dipelihara oleh para pembentuknya dan generasi selanjutnya yang diwarisi kebudayaan tersebut. (Nata, 2010: 49)

Kebudayaan yang diwariskan itulah yang disebut dengan sebuah tradisi. Tradisi di sini maksudnya adalah membaca ayat Al-Qur`an beserta surat-surat pilihan seperti surat al-Ikhlas, surat al-Falaq dan surat Annas. Di baca pada acara kematian, acara Yasinan, acara Tahlilan, acara Takziyah dan peresmian rumah baru. Pada setiap tradisi tersebut, biasanya surat yang dibacakan beragam tergantung acara atau kejadian yang sedang terjadi. Salah satu surat yang 
sering ditradisikan oleh masyarakat membacanya adalah surat Yasin. Mereka beranggapan surat ini memiliki fadhilah yang besar.

Setiap daerah pasti menyimpan potensi kearifan lokal sebagai wujud khazanah intelektual yang diekspresikan melalui ritual budaya masing-masing. Salah satu dari potensi kearifan lokal itu adalah ritual budaya agama dan kegiatan Yasinan dan Tahlilan yang sudah melekat pada sebagian masyarakat muslim Indonesia, termasuk di Nagari Balimbing sebagai Nagari yang memilki kearifan lokal dan menyimpan potensi budaya agama yang beragam dan khas yang belum tentu dimiliki oleh daerah lain.

Adapun pengaplikasian tradisi pembacaan surat Yasin yang sudah ada di masyarakat dan biasanya berbeda antara satu daerah dengan daerah lainnya. Sebagai contoh, misalnya: di Desa Palem Kecamatan Campuradat yaitu pembacaan tradisi Yasinan di desa ini dilakukan secara bersamasama dan dipimpin atau dipandu oleh ketua jamaah. Pembacaan tradisi Yasinan ini dibacakan secara tartil dan dibaca satu kali saja. Setelah itu, lalu di baca surat Al-Ikhlas, Al-Falaq dan AnNas. (Nur Faktu Rohman, 2018: 72)

Sementara itu, di Nagari Balimbing juga ada salah satu tradisi ritual pembacaan surat Yasin pada saat peristiwa kematian. Selain dibaca saat jenazah disemayamkan di rumah duka dan pada malam tahlilan, ada satu lagi tradisi pembacaaan surat Yasin yaitu di kuburan yang dilakukan selama tujuh hari berturut-turut terhitung semenjak jenazah dikuburkan. Adapun waktu pembacaannya adalah setiap pagi dan petang hari.
Dalam hal ini, dari hasil wawancara penulis dengan Bapak N. Pakiah Marajo (Ulama Nagari Balimbing) pada hari Selasa 15 Oktober 2020, Jam 16.00 WIB, diketahui bahwa tradisi pembacaaan surat Yasin di kuburan selama tujuh hari ini merupakan sebuah ritual yang dianggap unik. Hal yang menarik di sini adalah proses upacara kematian yang berbeda dengan daerah lain, yaitu mulai dari hari pertama dikuburkan sampai hari ketujuh keluarga datang ke kuburan untuk membacakan surat Yasin dan mengantarkan doa di waktu pagi dan petang kepada mayat yang telah disemayamkan. Kemudian pendapat ini diperkuat oleh Bapak Darimi Dinri (Ulama Nagari Balimbing) pada hari Kamis 17 Oktober 2020, Jam 19.00 WIB yang mengatakan pembacaan surat Yasin di kuburan ini sangat diutamakan bagi anak yang ditinggalkan si mayat, dikarenakan doa anak yang akan sampai kepada orang tuanya, lafaz do`a tersebut terdapat dalam Qs. At-Thur: 21

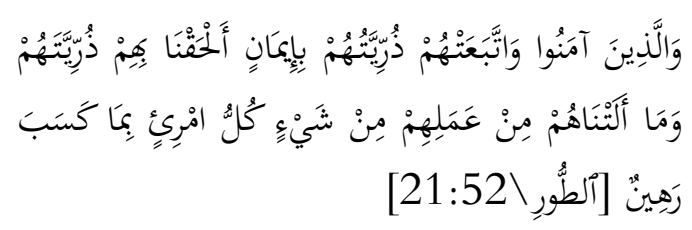

Artinya: "Dan orang-orang yang beriman, dan yang anak cucu mereka mengikuti mereka dalam keimanan, Kami hubungkan anak cucu mereka dengan mereka, dan Kami tiada mengurangi sedikit pun dari pahala amal mereka. Tiap-tiap manusia terikat dengan apa yang dikerjakannya"

Bedasarkan ayat di atas juga diperkuat oleh Hadist Rasulullah Saw yang diriwayatkan oleh Abu Hurairah: 


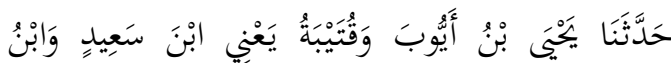

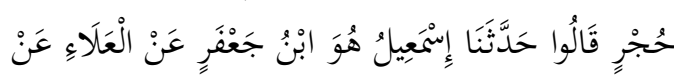

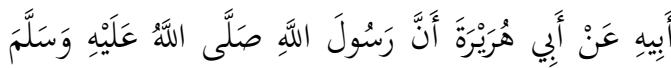

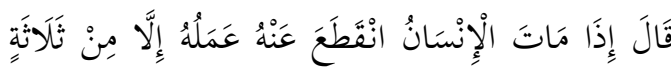

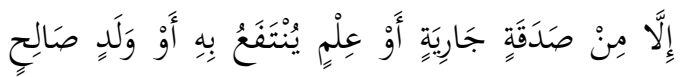

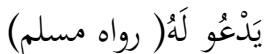

Artinya: Telah menceritakan kepada kami Yahya bin Ayyub dan Qutaibah yaitu Ibnu Sa'id-dan Ibnu Hujr mereka berkata; telah menceritakan kepada kami Isma'il -yaitu Ibnu Ja'far- dari Al 'Ala' dari Ayahnya dari Abu Hurairah, bahwa Rasulullah shallallahu 'alaihi wasallam bersabda: "Apabila salah seorang manusia meninggal dunia, maka terputuslah segala amalannya kecuali tiga perkara; sedekah jariyah, ilmu yang bermanfa'at baginya dan anak shalih yang selalu mendoakannya." (HR. Muslim: 3084) (Lidwa Pustaka i-Software-Kitab 9 Imam Hadist)

Hadist di atas menjadi landasan bagi masyarakat Nagari Balimbing, untuk membudayakan membaca dan mengamalkan Al-Qur`an pada prosesi upacara kematian, terutama pada waktu pagi dan petang selama tujuh hari dimulai saat hari pertama dikuburkan. Bagi masyarakat Nagari Balimbing membacakan Al-Qur`an khususnya surat Yasin oleh ahli waris di kuburan dianggap sebagai bentuk dari doa anak yang shaleh, dengan harapan bacaan itu akan sampai kepada ahli kubur dan meringankan siksa kuburnya.

Berdasarkan wawancara penulis dengan beberapa narasumber lainnya yaitu Bapak Dt. Majo Indo, Bapak N.Pakiah Marajo, Bapak Darimi Dindri dan Ibu H. Nijar mereka mengatakan bahwa Sejarah dari tradisi ini sudah turun-temurun diwariskan oleh nenek moyang. Praktek pembacaan surat Yasin ini dilakukan di kuburan selama tujuh hari berturut-turut di waktu pagi dan petang, keluarga dan khususnya anak si mayat mengantarkan doa kepada ahli kubur. Makna dari tradisi ini adalah agar kita manusia yang masih hidup senantiasa mengingat kematian dan selain itu dalam rangka mendoakan keluarga yang telah meninggal dunia.

Tradisi ini merupakan bentuk dari upaya menghidupkan Al-Qur'an didalam kehidupan atau disebut dengan Living Qur'an. Living Qur`an yang dimaksud dalam pembahasan ini adalah kajian atau penelitian ilmiah tentang berbagai peristiwa sosial kegamaan terkait dengan kehadiran Al-Qur`an atau keberadaan Al-Qur'an di sebuah komunitas muslim tertentu (Ridhoul Wahidi, 2013: 105). Dalam hal ini peneliti sebenarnya mencoba mengungkap fenomena yang bersinggungan atau terkait dengan AlQur`an yang hidup ditengah-tengah masyarakat Nagari Balimbing atau bisa disebut dengan Qur'an in Everyday Life yakni makna atau fungsi AlQur`an yang rill dipahami oleh masyarakat Nagari Balimbing. Salah satunya adalah tradisi pembacaan surat Yasin pagi dan petang di kuburan selama tujuh hari di Nagari Balimbing yang merupakan sebuah ritual keagamaan saat terjadinya kematian di Nagari Balimbing.

Bedasarkan uraian di atas, dapat diketahui bahwa tradisi pembacaan surat Yasin pagi dan petang di kuburan selama tujuh hari di Nagari Balimbing merupakan bentuk respon masyarakat Nagari Balimbing berupa resepsi mereka terhadap teks Al-Qur`an dan ini 
sudah membuktikan bahwa Al-Qur`an itu hidup di tengah-tengah masyarakat Nagari Balimbing dan menjadi sebuah tradisi serta ritual keagamaan secara turun-temurun.

Bagi penulis, fenomena ini menarik untuk dikaji dan diteliti sebagai model alternatif bagi suatu komunitas sosial masyarakat muslim untuk selalu berinteraksi dengan AlQur`an. Oleh karena itu, dalam penelitian ini akan mengulas sekilas bentuk Living Qur'an yang berkembang di Nagari Balimbing. Penulis mengacu pada penelitian tentang fenomena tradisi pembacaan surat Yasin pagi dan petang di kuburan selama tujuh hari di Nagari Balimbing, Kecamatan Rambatan. Penelitian ini diharapkan menghadirkan pemahaman inklusif kepada semua kalangan untuk senantiasa menghidupkan Al-Qur`an dalam kehidupan.

\section{METODE PENELITIAN}

Jenis penelitian dalam penulisan ini adalah penelitian lapangan (field research) dengan menggunakan pendekatan kualitatif. Penelitian ini termasuk kedalam penelitian Living Qur'an yang bisa dimaknai sebagai: teks Al-Qur'an yang hidup dalam masyarakat. Pendekatan ini berusaha memotret proses interaksi masyarakat terhadap Al-Qur'an, yang tidak sebatas pada pemaknaan teksnya, tetapi lebih ditekankan pada aspek penerapan teksteks Al-Qur'an dalam kehidupan sehari-hari. Sedangkan metode yang penulis gunakan adalah metode studi kasus.

Metode yang dipakai dalam penelitian ini adalah wawancara mendalamterhadap tokoh alim ulama, cadiak pandai di Nagari Balimbing.
Metode ini digunakan untuk menggali data tentang sejarah tradisi pembacaan surat Yasin pagi dan petang di kuburan selama tujuh hari dan apa makna yang didapat dari tradisi tersebut.

Penulis juga menggunakan metode analisis deskripitif karena metode ini sering digunakan untuk menjawab rumusan masalah penelitian dengan kata tanya " apa " dan "bagaimana", seperti rumusan masalah yang terdapat dalam penelitian ini untuk menyediakan informasi, penjelasan, alasan-alasan dan pertanyaanpertanyaan mengapa sesuatu hal bisa terjadi.

\section{HASIL DAN PEMBAHASAN}

\section{Deskripsi Nagari Balimbing \\ Asal Usul Dan Sejarah Nagari Balimbing}

Sejarah Pertama dari: Bapak Sy.Dt.Rajo Mangkuto (Amdan Umar dkk, 2015: 13). Ninik Moyang Masyarakat di Kenagarian Balimbing berasal dari Puncak Gunung Merapi yang turun Ke Pariangan dan terus ke Batu Basa, Galo Gandang. Dari Galo Gandang turun ke Bukit Taratai. Di Jorong Balimbing ada 16 Ninik Mamak atau orang 4 Jinih. Dari 16 Ninik Mamak yang ada masing-masing berpencar, diantaranya:

Ada yang pergi ke Bukit Taratai diantaranya:

- Dt. Kayo

- Dt. Rajo Mangkuto

- Dt. Tumanggung

Ada yang pergi ke Puncak Kampai di ujung Bukit Taratai diantaranya:

- Dt. Cahayo Lipati

- Dt. Gadang

- Dt. Tan Majo Lelo 
- Dt. Maharajo Kayo Di talago pulutan

Kemudian ada yang pergi ke mejan-mejan di daerah arah ke Ombilin:

- Dt. Tumangkuto

- Dt. Sinaro Nan Putiah (berasal dari sandi mandah)

- Dt. Marajo ( Daerah Sumbu Kuniang )

Kemudian Dt. Tunaro dan Dt. Rajo Batuah (didaerah Guguik Simantuin)

- Dt. Tan Palawan (Daerah Bayang Tungga)

Kemudian di Simabur: Dt. Marajo Dirajo

- Dikubang tanjung Dt. Gamuak dibalai panjang daerah arah ke Ombilin

- Dan Dt. Rajo Malano daerah Padang Sarai

Setelah berpencar ke daerahdaerah, kemudian berkumpulah di Koto Tuo (yang sekarang sudah menjadi persawahan), maka timbul suatu inisiatif untuk membentuk suatu nagari, disitu direcanakan pembentukan suatu Nagari. Disana di rencanakan pembentukan suatu Nagari, dan harus mempunyai empat syarat supaya terbentuknya suatu Nagari, diantaranya adalah:

\section{Rumah Adat}

Disusun rumah adat/rumah gadang seperti yang ada sekarang termasuk rumah tuo Kampai Nan Panjang

\section{$>$ Masjid}

Masjid di bangun di lakuk api-api

\section{Balai Adat}

Tempat pertemuan (dulu di Bukit Percaturan) semacam balai adat
Labuh (jalan) dan

Tapian (Lapangan Permainan). (Amdan Umar dkk, 2015: 14)

Dan hasil pertemuan Ninik Mamak Kinawai dan balimbing di umumkan di Bukit Bunian. Kemudian seiring perkembangan waktu diadakanlah pertemuan di Bukit Percaturan guna melakukan musyawarah untuk mendirikan sebuah Nagari yang dihadiri oleh 56 orang dari daerah masing-masing diantaranya hadir:

- 12 orang perwakilan dari Balimbing

- 12 orang perwakilan dari Kinawai

- 12 orang perwakilan dari Sawah Kareh

- 12 orang perwakilan dari Bukittamasu

- 8 orang perwakilan dari Padang Pulai

Setelah melakukan musyawarah dibukit percaturan diperoleh lah hasil musyawarah diantaranya:

- 3 Suku jatuh ke kinawai, tiga suku jatuh ke balimbing dan 1 tanjung

Untuk menetapkan nama Nagari berasal dari sebuah teka teki yang terjadi didaerah Koto Tuo, tepatnya di lurah ( batang air ) Sumalik dekat perkampungan Koto Gadang, terjadilah teka teki disana, antara 2 orang ninik moyang, salah seorang diantaranya mengatakan kepada kawannya, coba kamu ambil buah yang ada dibatang kayu itu, setelah diambil dan dicoba makan, rasanya masam ini adalah pohon Balimbing maka yang satu lagi diambil kawan yang kedua dan dimakan dan rasanya pahit (Pohon Kina) lalu yang pahit itu dibuang lah kebatang air dan itulah nama batang air/lurah batang Kinawai yang masam 
tadi ditinggal dan dijadikan tempat tersebut bernama Balimbing, makanya Balimbing dan Kinawai itu tak bisa dipisahkan dengan status adatnya satu. (Amdan Umar dkk, 2015: 15)

\section{Kondisi Umum Nagari}

\section{Geografis}

Kanagarian Balimbing terdapat di Kecamatan Rambatan, Kabupaten Tanah Datar yang berbatasan dengan Kanagarian Rambatan di sebelah utara, Kanagarian Tigo Koto di sebelah barat, Kanagarian Simawang dan Kabupaten Solok di sebelah selatan dan Kecamatan Tanjung Emas di sebelah timur. Nagari ini terletak di daratan tinggi sehingga suhu daerah ini relatif rendah , dimana ketinggiannya berada diantara \pm 450-500 meter diatas permukaan laut (DPL), serta sebagian besar daerahnya terdiri dari bukit. Nagari Balimbing memiliki bentang alam/morfologi yang unik, sehingga Nagari Balimbing dikelilingi oleh perbukitan. Kondisi alam di Nagari Balimbing yang terdiri dari lima jorong ini sangat dipengaruhi oleh kondisi topografinya yang berbukit dan berlembah, sehingga Nagari Balimbing beriklim sedang dengan temperatur bervariasi antara $20^{\circ}-30^{\circ} \mathrm{C}$. Dengan curah hujan 1.500-2.000 mm. (Amdan Umar dkk, 2015: 18)

Batas antar jorong yang tergabung dalam Kanagarian Balimbing ditandai dengan batas alam seperti sungai, sawah dan perbukitan. Jorong yang tergabung dalam Kanagarian Balimbing antara lain:

Jorong Bukit Tamasu, dengan luas $\pm 150,59$ ha.

$\checkmark$ Jorong Sawah Kareh, dengan luas \pm 440,42 ha. $\checkmark$ Jorong Kinawai Kenagarian Balimbing berdasarkan hasil dari pengukuran dengan menggunakan GPS memiliki luas $\pm 2.422 \mathrm{Ha}$. Adapun yang menjadi pusat pemerintahan dalam Kanagarian Balimbing terdapat di Jorong Kinawai.

Penyebaran penduduk nagari Balimbing ini tidak merata hal ini bisa dilihat dari jumlah penduduk perjorongnya. Selain itu sebagian penduduk ada yang memiliki tempat tinggal yang dua, dikarenakan area lahan pertanian mereka yang jauh dari tempat tinggal mereka.

$\checkmark$ Jorong Kinawai, dengan luas \pm 844,09 ha.

$\checkmark$ Jorong Padang Pulai, dengan luas \pm 149,39 ha.

$\checkmark$ Jorong Balimbing, dengan luas \pm 837,51 ha. (Amdan Umar dkk, 2015: 18)

\section{Demografi}

\section{Jumlah dan Pertumbuhan Penduduk}

Secara teoritis disebutkan bahwa jumlah penduduk yang besar merupakan salah satu modal dasar pembangunan. Hal ini dimaksudkan apabila jumlah penduduk yang besar tersebut dapat diberdayakan sesuai kodrat, keahlian dan bidang kerjanya masing-masing. Sebaliknya apabila jumlah penduduk yang besar tadi tidak dapat diberdayakan dan dikendalikan secara bijak dan terencana bahkan akan menjadi beban pembangunan.

Berdasarkan data terakhir yang diterima dari Laporan Pengiriman Mutasi Penduduk Nagari Balimbing bahwa jumlah penduduk sebesar \pm 8.788 jiwa Sex Ratio 
Dalam penyusunan perencanaan pembangunan jangka menengah Nagari Balimbing, data kondisi tentang sex ratio penduduk suatu Nagari mutlak diperlukan karena akan mempengaruhi terhadap beberapa kebijakan dan ataupun program yang akan ditetapkan.

Berdasarkan data terakhir yang diterima dari Laporan Pengiriman Mutasi Penduduk Nagari Balimbing bahwa sex ratio penduduk daerah Nagari Balimbing adalah sebesar 8.788 jiwa.

\section{Kepadatan dan Penyebaran Penduduk}

Kepadatan penduduk Nagari Balimbing tergolong normal bila dibandingkan dengan kepadatan penduduk Nagari lainnya. Tingkat kepadatan penduduk daerah Nagari Balimbing menyebar di lima jorong karena merupakan tempat kediaman dari sejak dahulunya.

\section{Struktur Umur}

Kondisi struktur umur penduduk Nagari Balimbing sampai dengan akhir tahun 2009 tergolong komposisi struktur penduduk usia muda.

Sejarah Munculnya Tradisi Pembacaan Surat Yasin Pagi dan Petang di kuburan selama tujuh hari di Nagari Balimbing

Sejarah adalah sebuah catatan penting tentang sebuah peristiwaperistiwa yang terjadi dimasa lampau, baik yang berhubungan dengan asal usul, nenek moyang, adat istiadat dan sebuah kebiasaan yang telah dilakukan secara turun-temurun dan diyakini kebiasaan tersebut bernilai sakral. Sejarah merupakan hal yang sangat terpenting dalam mengkaji sebuah fenomena-fenomena yang menarik yang terjadi ditengah-tengah masyarakat, salah satunya sebuah fenomena tradisi yang sudah melekat dan turun temurun dari nenek moyang. Tradisi adalah sebuah kebiasaan yang dilakukan berulang-ulang dan menjadi sebuah simbol dalam upacara, baik upacara adat, keagamaan maupun kematian. Dalam sebuah tradisi yang terjadi ditengah-tengah masyarakat tentu ada tokoh yang sangat berkompeten dan mengetahui asal usul kapan sebuah tradisi tersebut muncul. Di Nagari Balimbing seseorang yang paham dengan tradisi ini disebut dengan Ulama Nagari Balimbing, dalam penelitian ini peneliti melakukan wawancara dengan beberapa ulama Nagari Balimbing. Wawancara pertama peniliti bersama Bapak N. Pakiah Marajo sebagai Informan I yang menjelaskan bagaimana sejarah munculnya Tradisi Pembacaan Surat Yasin Pagi dan Petang di kuburan selama tujuh hari di Nagari Balimbing. Adapun hasil wawancara dengan Bapak N. Pakiah Marajo Sebagai berikut:

"Sejarah Tradisi Pembacaan Surat Yasin Pagi dan Petang di kuburan selama tujuh hari di Nagari Balimbing tidak diketahui kapan pastinya karena hal tersebut sudah ada secara turuntemurun dibawa oleh nenek moyang ke Nagari Balimbing. Masyarakat Nagari Balimbing hanya meneruskan dan melestarikan dari tradisi tersebut, karena tradisi tersebut sebuah simbol pada upacara adat kematian di Nagari Balimbing ini" (Bapak N. Pakiah Marajo, 30 Mei 2021)

Hal senada juga disampaikan Bapak H. Darimi Dindri sebagai informan II sekaligus ulama dan pemuka masyarakat Nagari Balimbing, 
adapun hasil wawancaranya sebagai berikut:

"Untuk sejarah Tradisi Pembacaan Surat Yasin Pagi dan Petang di kuburan selama tujuh hari di Nagari Balimbing ini Bapak tidak mengetahui pasti kapan datangnya, karena Bapak hanya menerima saja dari nenek moyang terdahulu, dan tradisi ini sudah ada di Nagari Balimbing semenjak Nagari Balimbing ada. Dan ini juga sudah menjadi keyakinan masyarakat Nagari Balimbing, apabila ada salah seorang anggota keluarganya meninggal dunia maka mereka wajib untuk melaksanakan tradisi ini serta rangkaian ritualnya yaitu di waktu pagi dan petang selama tujuh hari berturutturut keluarga si ahli kubur mendatangi kubur si mayat. Dengan maksud menghantarkan doa agar simayat terebas dari azab kubur. Dan kenapa harus pagi dan petang, menurut cerita yang Bapak dengar bahwa diwaktu pagi dan petang si mayat sedang di azab dan membutuhkan pertolongan." (Bapak H. Darimi Dindri, 01 Juni 2021)

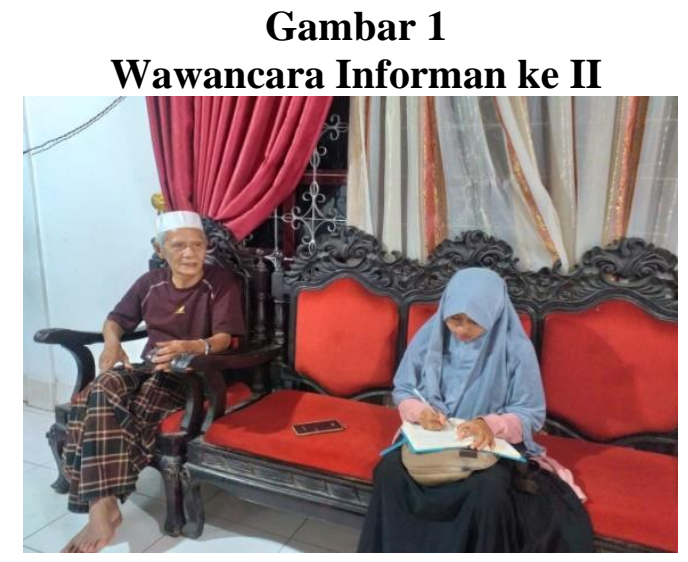

Seiring dengan pendapat Bapak N. Pakiah Marajo dan Bapak H. Darimi Dindri, Bapak H.Raja'in sebagai Informan ke III juga menjelaskan hal yang hampir sama yaitu:
"Mengenai asal usul tradisi ini Bapak tidak mengetahui pasti, karena tradisi ini sudah ada sejak dahulu, sejak Nagari Balimbing ini ada. Dan kita sebagai cucu dan cicit dari nenek moyang hanya mewarisi dan mentradisikan hal yang sudah ada turun-temurun dibawa oleh nenek moyang" (Bapak H. Raja'in, 05 Juni 2021)

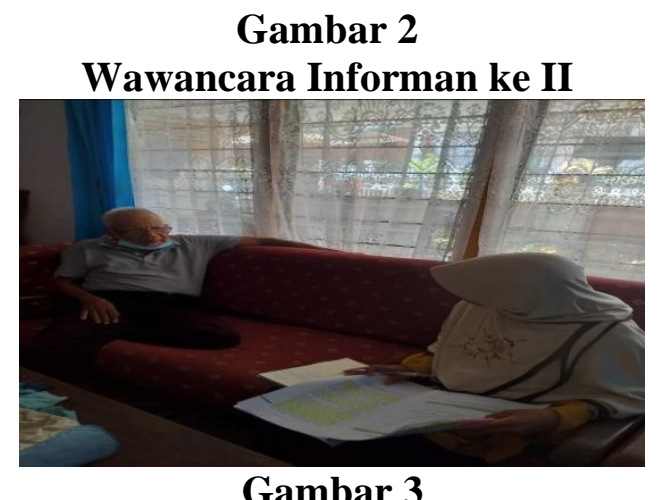

Wawancara Informan ke III

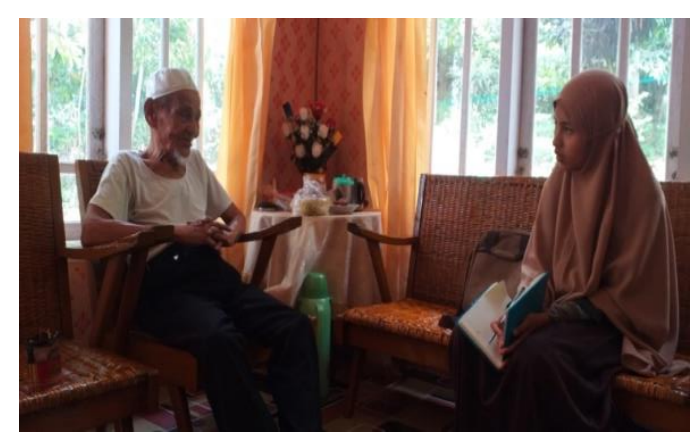

Senada juga yang dituturkan Bapak H. Dt. Majo Indo bahwa sejarah tradisi ini tidak tahu kapan pasti munculnya karena sudah ada dan sudah dilakukan secara turun-temurun dan tradisi ini merupakan bentuk pemahaman masyarakat dalam kehidupan beragama di Nagari Balimbing, karena sudah ada semenjak nenek moyang kita sebagai generasi selanjutnya kita hanya meneruskan yang sudah ada. (Bapak H. Dt. Majo Indo, 06 Juni 2021) 
Penjelasan diatas memberikan informasi bahwa sejarah Tradisi Pembacaan Surat Yasin Pagi dan Petang di kuburan selama tujuh hari di Nagari Balimbing ini tidak diketahui kapan pasti munculnya, karena tradisi ini sudah diterima secara turuntemurun dari nenek moyang dan sudah menjadi ritual upacara kematian saat salah satu masyarakat Nagari Balimbing yang meninggal dunia.

Bedasarkan yang peneliti amati di lapangan mengenai sejarah Tradisi Pembacaan Surat Yasin Pagi dan Petang di kuburan selama tujuh hari di Nagari Balimbing ini seluruh informan tidak begitu pasti mengetahui kapan tradisi ini muncul dan siapa yang membawa ke Nagari Balimbing, informan mengatakan bahwa tradisi ini sudah ada dan sudah turun -temurun dari nenek moyang.

\section{Pembacaan Surat Yasin Pagi dan Petang di Kuburan Selama Tujuh Hari di Nagari Balimbing}

Praktek adalah bentuk pengaplikasian sebuah fenomena yang terjadi di tengah-tengah masyarakat dan sudah melekat serta turun-temurun dilakukan dari generasi ke generasi selanjutnya. praktek pembacaan Surat Yasin ini dilakukan di kuburan pada waktu pagi dan petang selama tujuh hari berturut-turut. Pada praktek pelaksanaan tradisi ini keluarga si ahli kubur datang ke kuburan untuk mengantarkan doa di waktu pagi dan petang selama tujuh hari berturut-turut. Di dalam praktek ini terdapat rangkaian-rangkaian ritual upacara yang dilakukan mulai dari hari pertama dikuburkan sampai hari ketujuh.

\begin{abstract}
Peneliti melakukan wawancara dengan beberapa Narasumber mengenai bagiamana praktek pembacaan Surat Yasin pagi dan petang di kuburan selama tujuh hari di Nagari Balimbing ini.
\end{abstract}

Berdasarkan hasil wawancara peneliti bersama Bapak $H$. Darimi Dindri, beliau mengatakan bahwa:

"Praktek tradisi ini dilakukan di kuburan di waktu pagi dan petang selama tujuh hari berturut-turut, keluarga si ahli kubur mengantarkan doa kepada ahli kubur dengan niat ahli kubur terbebas dari disiksa kubur, dari cerita yang Bapak dengar kenapa harus diwaktu pagi dan petang, dikarenakan di waktu itu si mayat sedang di azab dan membutuhkan pertolongan, yaitu pertolongan doa dari keluarga terkhusus anaknya yang mendoakan" (Bapak H. Darimi Dindri, 2020)

\section{Gambar 4}

Praktik Pembacaan Yasin di kuburan di waktu Pagi (Kuburan Abu Nawas)

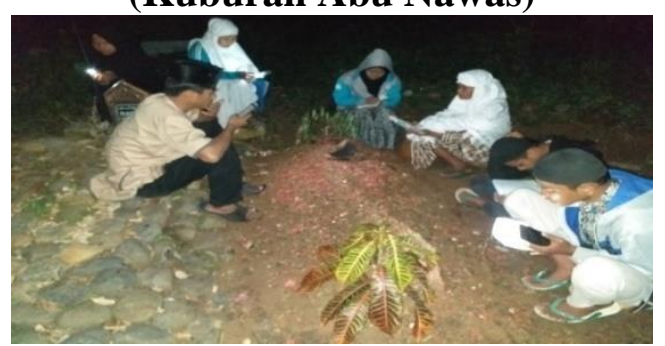

Gambar 5

Praktik Pembacaan Yasin di kuburan di waktu Pagi (Kuburan Irwan)

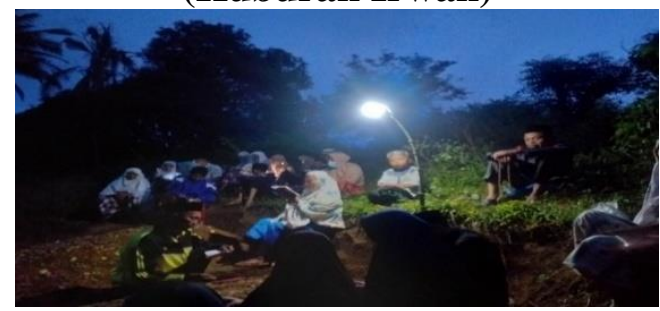




\section{Gambar 6}

Praktik Pembacaan Yasin di kuburan di waktu Petang

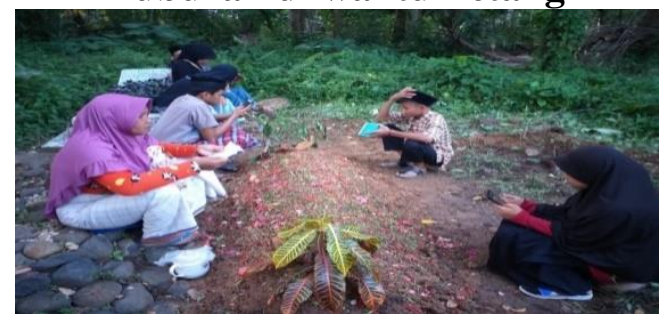

Wawancara peneliti selanjutnya bersama Bapak Azzumar (Keluarga Alm. Irwan) yang melakukan praktek pembacaan surat Yasin dikuburan selama tujuh hari beliau menerangkan prakek-praktek rangkaian kegiatan pelaksanaan pembacaan Surat Yasin Pagi dan Petang di kuburan selama tujuh hari yaitu:

"Praktek ini dilakukan selama tujuh hari berturut-turut dilaksanakan dikuburan oleh ahli waris selama tujuh hari diwaktu pagi dan petang. Rangkaian pelaksanaannya adalah pertama ahli waris mengucapkan salam dikubur dan menyiram air talqin dikuburan.

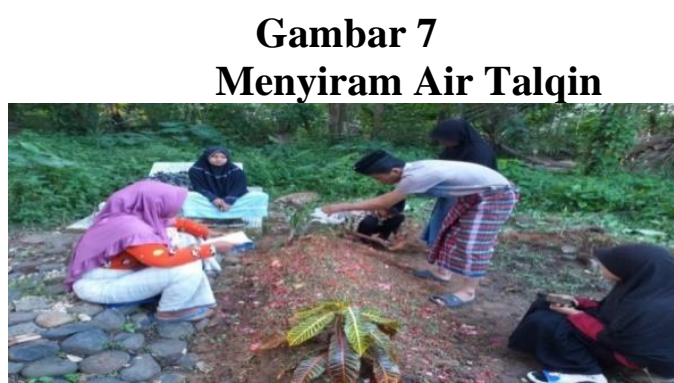

Setelah itu ahli waris membaca Surat Yasin secara bersama-sama, duduk mengelilingi kuburan dan selanjutnya membaca doa siksa kubur. Pada hari pertama membaca doa siksa kubur hari pertama dan begitu seterusnya sampai hari ketujuh. Doa siksa kubur ini dibacakan oleh laki-laki atau orang yang dituakan yang datang mengantarkan doa kekuburan."
Gambar 8

Doa Siksa Kubur Hari 1

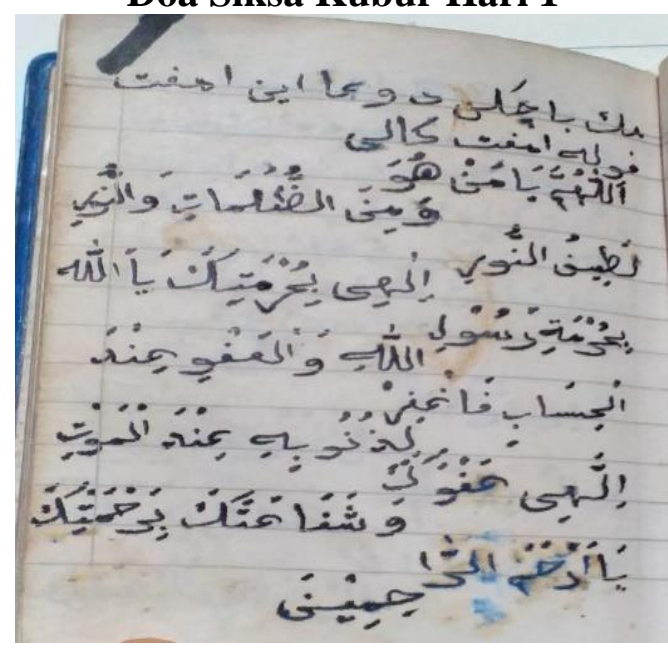

Gambar 9

Doa Siksa Kubur Hari 2

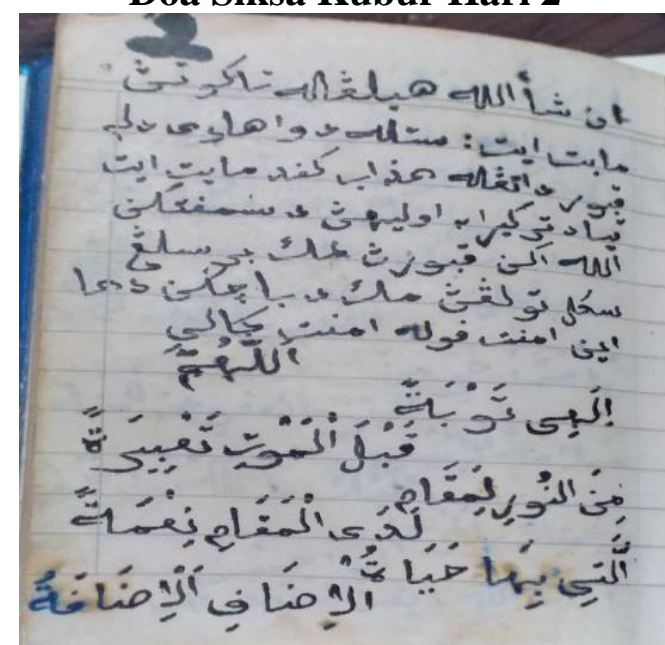

Gambar 10

Doa Siksa Kubur Hari 3

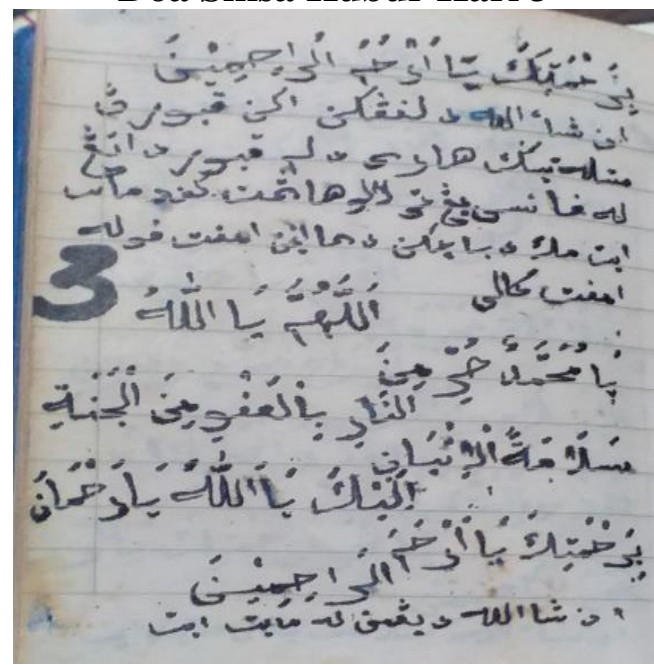


Gambar 11

Doa Siksa Kubur Hari 4

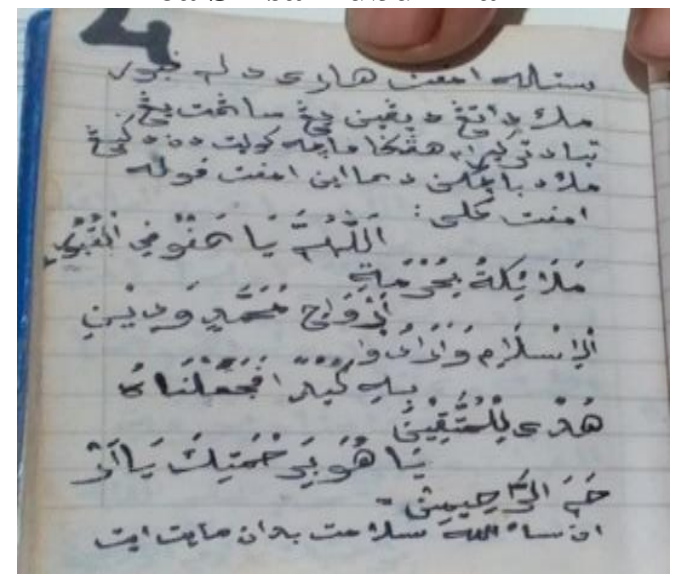

Gambar 11

Doa Siksa Kubur Hari 5

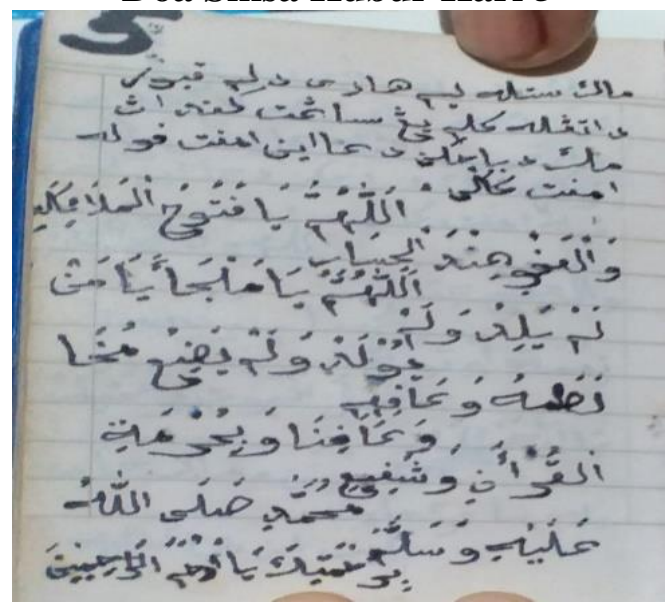

Gambar 12

Doa Siksa Kubur Hari 6

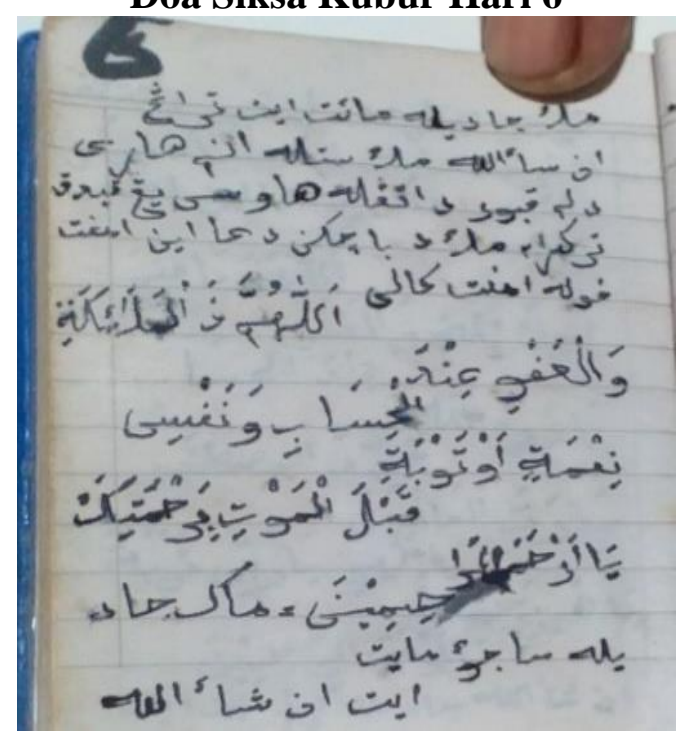

Gambar 13

Doa Siksa Kubur Hari 7

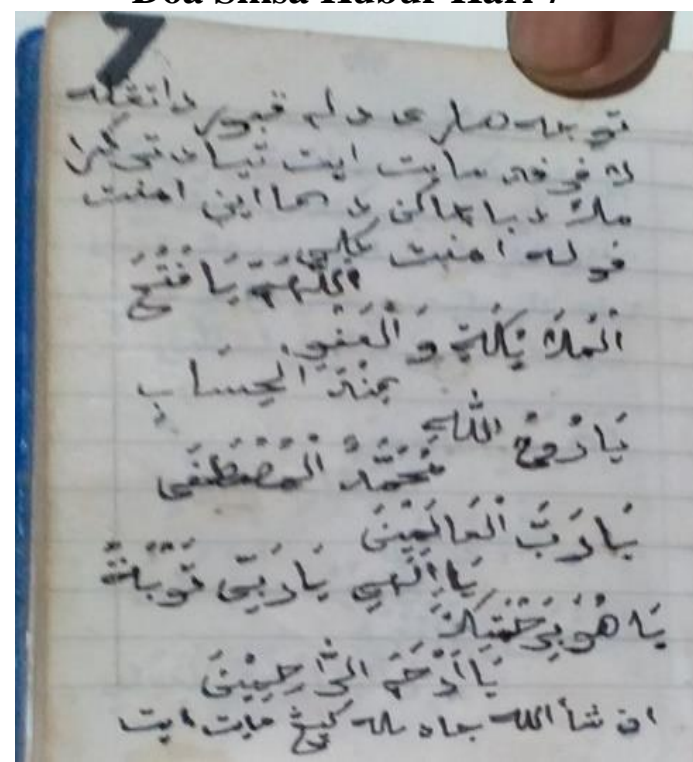

Gambar 14

Wawancara dengan Bapak Azzumar

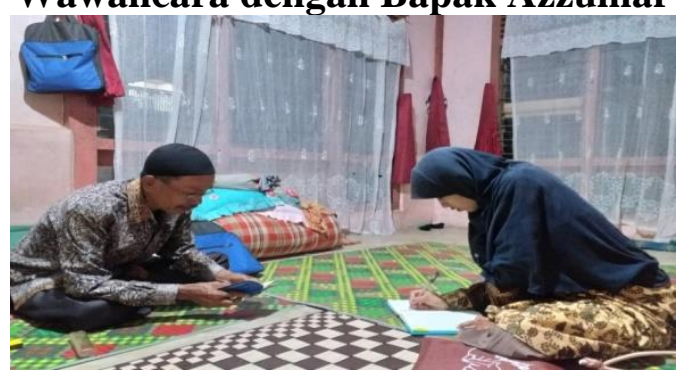

"Hal senada juga disampaikan oleh Hj.Nijar mengenai Praktek Pembacaan Surat Yasin Pagi dan Petang di kuburan selama tujuh hari bahwa ada tujuh bacaan doa siksa kubur yang dibaca selama pagi dan petang dikuburan selama tujuh hari berturut-turut dengan niat agar ahli kubur terbebas dari siksa kubur."

\section{Gambar 15}

Wawancara dengan $\mathrm{Hj}$. Nijar

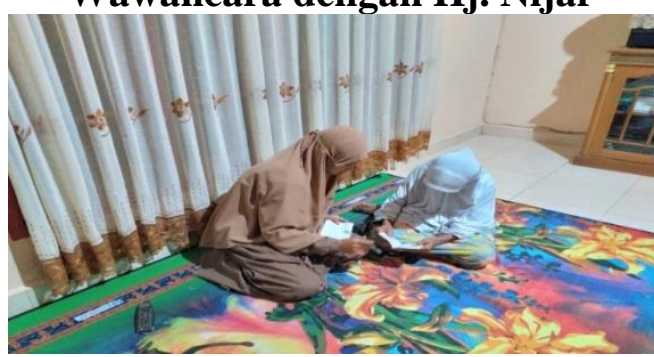


Makna Pembacaan Surat Yasin Pagi dan Petang di kuburan selama tujuh hari di Nagari Balimbing

Wawancara peneliti bersama Bapak H. Darimi Dindri mengatakan bahwa:

"Makna tradisi Pembacaan Surat Yasin Pagi dan Petang di kuburan selama tujuh hari di Nagari Balimbing ini adalah agar kita yang masih hidup senantiasa mengingat kematian, bahwa suatu saat pasti kita akan diposisi mereka dan kita yang akan didoakan oleh orang yang kita tinggalkan.”

Senada yang disebutkan Bapak $\mathrm{H}$. Darimi Dindri, Bapak H. Rajai'n juga menyebutkan bahwa makna dari tradisi ini menjadikan kita agar selalu mengingat kematian yang tidak tau kapan akan datang dan agar kita mempersiapkan diri."

Sama halnya yang disebutkan oleh Hj. Nijar dan Bapak Azzumar bahwa makna tradisi Pembacaan Surat Yasin Pagi dan Petang di kuburan selama tujuh hari di Nagari Balimbing ini adalah mengingatkan kita kepada kehidupan setelah mati yaitu dengan berziarah ke kuburan maka kita akan ingat seandainya kita yang berada diposisi tersebut dan juga tradisi ini merupakan bentuk dari kekayaan dan kearifan lokal nagari Balimbing yang sudah dilaksanakan secara turuntemurun.

Sejarah munculnya tradisi pembacaan surat Yasin pagi dan petang di kuburan selama tujuh hari di Nagari Balimbing

Sejarah munculnya tradisi pembacaan surat Yasin pagi dan petang di kuburan selama tujuh hari di Nagari Balimbing tidak ada yang mengetahui pasti kapan datangnya, karena tradisi tersebut sudah ada dan sudah dilaksanakan secara turun-temurun oleh masyarakat Nagari Balimbing.

Temuan hasil penelitian tradisi pembacaan surat Yasin pagi dan petang di kuburan selama tujuh hari di Nagari Balimbing menunjukkan bahwa ulama dan tokoh yang terkait mengenai tradisi ini tidak mengetahui pasti kapan munculnya tradisi ini di Nagari Balimbing. Segala bentuk informasi hanya mereka dapatkan secara turuntemurun dan tidak ada catatan, sumber pasti mengenai sejarah tradisi ini.

Tradisi ini didalam ajaran Islam tidak bertentangan dan juga tidak dilarang, karena di dalam ajaran Islam menganjurkan untuk berziarah kubur yaitu dengan niat mengantarkan doa kepada ahli kubur agar ahli kubur terbebas dari siksa kubur. Dalil tentang ziarah kubur terdapat dalam Hadist Rasulullah Saw:

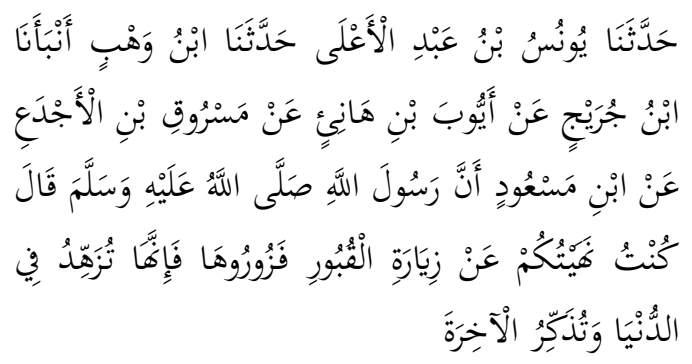

Artinya: "Telah menceritakan kepada kami Yunus bin Abdul A'la berkata, telah menceritakan kepada kami Ibnu Wahb berkata, telah memberitakan kepada kami Ibnu Juraij dari Ayyub bin Hani` dari Masruq Ibnul Ajda' dari Ibnul Mas'ud bahwa Rasulullah shallallahu 'alaihi wasallam bersabda: "Aku telah melarang kalian dari ziarah kuburan, sekarang berziarahlah. Karena ia dapat menjadikan zuhud di 
dunia dan ingat dengan akhirat. " (HR. Ibnu Majah: 1560)

Kemudian terkait dengan pembacaan surat Yasin dikuburan tidak pula dilarang oleh ajaran Islam, karena membaca Al-Qur`an boleh dimana saja asalkan tempatnya bersih dari hadast dan najis. Kenapa surat Yasin yang dibaca karena surat Yasin adalah jantungnya Al-Qur`an dan di dalam kandungan surat Yasin banyak membahas tentang kematian dan kehidupan setelah mati yaitu alam kubur.

\section{Praktek pembacaan surat Yasin pagi dan petang di kuburan selama tujuh hari di Nagari Balimbing}

Pelaksanaan Praktek Tradisi pembacaan surat Yasin pagi dan petang di kuburan selama tujuh hari di Nagari Balimbing ini dilaksanakan sesuai dengan prosedur yang sudah mereka terima secara turun-temurun dari nenek moyang, mulai dari membaca Surat Yasin dikuburan sampai dengan membaca doa- doa untuk ahli kubur. Selain membacakan surat Yasin dikuburan juga ada membacakan doa siksa kubur yang bacaannya berbeda setiap hari dibaca tujuh hari selama berturut-turut di kuburan. Doa ini bertujuan untuk meringankan azab kubur si ahli kubur. Sebagaimana disebutkan dalam Hadist Rasulullah Saw:

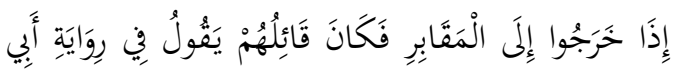

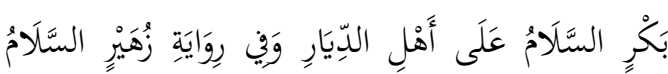

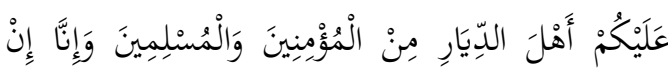

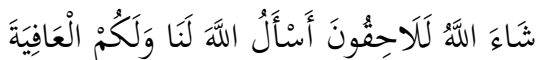

Artinya: Telah menceritakan kepada kami Abu Bakar bin Abu Syaibah dan Zuhair bin Harb keduanya berkata, telah menceritakan kepada kami Muhammad bin Abdullah Al Asadi dari Sufyan dari Alqamah bin Martsad dari Sulaiman bin Buraidah dari bapaknya ia berkata; Rasulullah shallallahu 'alaihi wasallam mengajarkan kepada mereka apa yang mesti mereka kerjakan apabila mereka hendak keluar ziarah kubur. Maka salah seorang dari mereka membaca do'a sebagaimana yang tertera dalam riwayat Abu Bakar; "As Salaamu 'Ala Ahlid Diyaar -Sementara Dalam Riwayat Zuhair- As Salaamu 'Alaikum Ahlad Diyaari Minal Mukminiin Wal Muslimiin Wa Innaa Insyaa'Allahu Bikum Laahiquun Asalullaha Lanaa Walakumul 'Aafiyah (Semoga keselamatan tercurah bagi penghuni (kubur) dari kalangan orang-orang mukmin dan muslim dan kami insya Allah akan menyulul kalian semua. Saya memohon kepada Allah bagi kami dan bagi kalian Al 'Afiyah (keselamatan)." (HR. Muslim: 1620)

Pada tradisi ini pembacaan surat Yasin di kuburan di Nagari Balimbing ini dilaksanakan pada waktu pagi dan petang karena di saat pagi dan petang Allah Swt menganjurkan untuk berzikir dan bertasbih kepada beliau sebagaimana firmannya dalam Qs. AlAhzab ayat 41- 42:

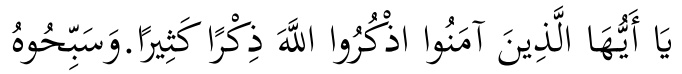

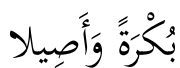

Artinya: " Hai orang-orang yang beriman, berzikirlah (dengan menyebut nama) Allah, zikir yang sebanyakbanyaknya. Dan bertasbihlah kepadaNya di waktu pagi dan petang”. 
Maknapembacaan surat Yasin pagi dan petang di kuburan selama tujuh hari di Nagari Balimbing

Makna merupakan sebuah pesan yang terkandung dari sebuah pelaksanaan kegiatan atau aktivitas dalam kehidupan sehari-hari. Makna dari sebuah tradisi pembacaan surat Yasin pagi dan petang di kuburan selama tujuh hari di Nagari Balimbing ini adalah:

Pertama, mendekatkan diri kepada Allah Swt dengan berziarah ke kubur ahli kubur dan mengantarkan doa agar ahli kubur terbebas dari siksa kubur. Mengingat bahwa suatu saat kita pasti berada di posisi ahli kubur yang kita antarkan doa.

Kedua, sebagai amal ibadah, ketika seorang Muslim meninggal dunia, maka istri, anak, tahta dan jabatan akan meninggalkannya, tidak ada selain doa dari keluarga dan terutama anak yang shaleh yang akan menolongnya di alam kubur.

Ketiga, Ketenangan hati, karena segala perbuatan tergantung dengan hati. Dengan adanya kegiatan tradisi pembacaan surat Yasin pagi dan petang di kuburan selama tujuh hari di Nagari Balimbing ini, menjadi penenang hati dengan berzikir kepada Allah Swt dan mengingat mati serta menambah keimanan kepada Allah Swt.

Tradisi Pembacaan Surat Yasin di Kuburan Pagi dan Petang Selama Tujuh Hari di Nagari Balimbing tidak menyalahi ajaran agama Islam karena Ziarah kubur tidak dilarang kemudian surat yang dibacakan di tradisi ini merupakan ayat Al-Qur'an yaitu Surat Yasin sebagai jangtungnya Al-Qur'an. Fadhilah surat Yasin yaitu dapat meringankan siksa kubur si ahli kubur dan dalam tradisi ini juga dibacakan bacaan "siso kubua" (siksa kubur). Kemudian terkait dengan pelaksanaan waktu tradisi ini yaitu pada saat pagi dan petang dikarenakan pada saat itu waktu yang paling bagus untuk berzikir dan bertasbih kepada Allah Swt sebagaimana yang disebutkan dalam Al-Qur'an Surat Al-Ahzab: 41- 42.

\section{KESIMPULAN}

Living Qur`an adalah kajian atau penelitian ilmiah tentang berbagai peristiwa sosial terkait dengan kehadiran Al-Qur an atau keberadaan Al-Qur'an di sebuah komunitas Muslim tertentu.

Pertama: Dari hasil penelitian yang berlokasi di Nagari Balimbing, Tradisi pembacaan surat Yasin pagi dan petang di kuburan selama tujuh hari di Nagari Balimbing merupakan tradisi turuntemurun yang sampai saat ini tetap dilaksanakan. Dalam hal ini Masyarakat Nagari Balimbing mempercayai bahwa pembacaan Surat Yasin pagi dan petang di kuburan selama tujuh hari ini akan membebaskan ahli kubur dari siksa kubur.

Kedua: Pelaksanaan kegiatan pembacaan Surat Yasin pagi dan petang di kuburan selama tujuh hari di Nagari Balimbing merupakan bentuk pemahaman masyarakat Nagari Balimbing terhadap Al-Qur`an pada saat terjadinya kematian. Dengan membaca Surat Yasin dan doa siksa kubur yang berbeda bacaannya setiap hari mulai dari hari pertama sampai hari ketujuh bertujuan untuk meringankan azab kubur si ahli kubur. 
Ketiga: Mengenai makna yang terkandung dalam Tradisi pembacaan surat Yasin pagi dan petang di kuburan selama tujuh hari di Nagari Balimbing meliputi makna objektif dan makna ekspresif. Sebagai makna objektifnya, kegiatan membaca Surat Yasin pagi dan petang di kuburan selama tujuh hari ini merupakan tardisi turuntemurun yang sudah lama dilaksanakan di Nagari Balimbing, kegiatan ini dipandang suatu hal yang baik dan mendatangkan manfaat baik dari segi duniawi maupun akhirat, dengan membaca Surat Yasin di kuburan menjadikan pribadi yang ingat terhadap akhirat dan kematian, yakni dengan mengingat mati akan menambah keimanan kepada Allah Swt. Sebagai makna ekspresifnya, tradisi ini merupakan sarana untuk meningkatkan kualitas diri dalam hal ibadah dan menambah pahala dengan mengirimkan doa kepada ahli kubur agar ahli kubur selamat dan terbebas dari siksa kubur.

\section{REFERENSI}

\section{Buku}

Al-Qur`anul Karim

Abdullah, Abu Muhammad. 2012. Sunan ad-Darimi Juz 2. Bairut: Dar al-Kotob alllmiyah.

Abdullah, M. Amin, 1996. Studi Agama: Normativitas atau Historitas. Cet. Ke-1. Yogjakarta: Pustaka Pelajar.

Achmadi, Abu. Natbuko, Cholid. 2009. Metodologi Penelitian, Jakarta: PT. Bumi Aksara.

AG,Muhaimin. 2011. Islam Dalam Bingkai Budaya Lokal: Potret Dari Cerebon, Terj.Suganda. Ciputat: PT. Logos Wacana Ilmu.
Aizid, Rizem. 2013. Mukjizat Yasin,Tahlil dan Ziarah Kubur, Yogjakarta: DIVA Press.

al-Jafry, Ahmad Filyan. 2012. DetikDetik Menuju Kematian, Jakarta: Aulia

Al-Tabrani, al-Mu jam al-Shagir, Juz: 2.

Arifin, Gus. 2010. Do`a-doa Lengkap Istighasah. Jakarta: Kompas Gramedia

Departemmen Agama RI.2015. Surat Yasin Tajwid Warna dan Tahlil Plus Doa Ayat-ayat Rezeki. Jakarta: Shahih.

Eny, Winayarti. 2020. Action Research dalam Pendidikan (Antara Teori dan Praktik). Semarang: UNIMUS Press.

Fanani, Muhyar. 2010. Metode Study Islam: Aplikasi Sosiologi Pengetahuan Sebagai Cara Pandang. Yogjakarta: Pustaka Pelajar.

Hanafi, Hasan. 2003. Oposisi Pasca Tradisi. Yogjakarta: Sarikat.

Hasan, Khalil Rasyad. 2009. Tarikh Tasryi. Jakart: Grafindo Persada.

Imam Nasa`i, Sunan an-Nasa`i alKubra, Juz: 6.

Ismail, Ibnu Nu`man Daud. Salim, Ibnu Muhammad. $2018 \quad$ Yaasiin Karamah Khasiat dan Keutaman Surat Yasin. Tanggerang: Al-Aras.

J. Moleong, Lexy. 2006. Metode Penelitian Kualitatif. Bandung ; PT. Remaja Rosdakarya.

Koentjaraningrat. 1993. Metode Penelitian Masyarakat. Jakarta: PT. Gramedia Pustaka Utama.

Muhadjir, Noeng. 1998. Metodologi Penelitian Kualitatif Pendekatan Positivistik, Rasionalistik, Phenomenologik, dan Realisme Methaphisik Telaah Study Teks 
dan Penelitian Agama. Yogjakarta: Rake Sarasin.

Mulyadi, Arif dan Khalid. 2014. AlLamah Kamal Faqih Imani, Tafsir Nurul Qur`an, jilid 15.Jakarta: Nur Al-Huda.

Muslich, Hanief. 2001. Ziarah Kubur Wisata Spritual. Jakarta: AlMawardi Prima.

Nata, Abudin. 2010. Metodologi Studi Islam, Jakarta: Rajawali Pers.

Newman. W. Lawrence, 2013. Metodologi Penelitian Sosial: Pendekatan Kualitatif dan Kuantitatif (edisi 7), Jakarta: PT. Indeks.

Shihab, Quraish. 1994. Membumikan Al-Qur'an. Bandung: Mizan.

Shihab, Quraish. 2002. Tafsir AlMisbah. Jakarta: Lentera Hati.

Sholikhin, Muhammad. 2010. Ritual dan Tradisi Islam Jawa. Yogjakarta: Narasi.

Soekanto, Soejono. 1993. Sosiologi. Suatu Pengantar, Jakarta: PT. Raja Grafindo Persada. ZTF, Pradana Boy (Ed. dan pent ). 2002. Agama Empiris, Agama dalam Pergumulan Realitas Sosial, Cet. I, Yogjakarta: Pustaka Pelajar dan Pustaka LP21F.

Sukmadinata. 2006. Metode Penelitian Pendidikan. Bandung: Remaja Rosdakarya.

Sunan ad-Darimi, Bāb fì Fadl Yāsīn, Juz: 2

Syamsuddin, Sahiron. 2007. Metodologi Penelitian Living Qur'an dan Hadis . Malang: Teras.

Syamsyi, M. 2001. Kado Sang Mayat. Surabaya: Target Press.

Syamsyuddin,S. 2007. "Ranah-Ranah Penelitian Dalam Studi Al-Qur 'An Dan Hadist" dalam M. Mansyur, dkk, Metodologi Penelitian Living
Qur`an dan Hadist. Yogjakarta ; TH. Press.

Syarbini, Amirulloh. Jamhari, Sumantri. 2012. Kedahsyatan Membaca Al-Qur'an. Bandung: Ruang Kata Imprint Kawan Pustaka.

Sztompka, Piotr. 2007. Sosiologi Perubahan Sosial. Jakarta: Prenada Media Group.

Tanzeh,Ahmad. 2009. Pengantar Metodologi Penelitian. Yogjakarta; Teras.

Ubaidi, Ahmad Hasbillah. 2019 Ilmu Living Qur"an dan Hadis ; Ontologi, Epistimologi, Aksiologi . Banten: Yayasan Darussunnah.

Umar, Amdan, dkk. 2015. Sejarah dan Adat Istiadat Nagari Balimbing. Balimbing.

Warson, Ahmad Munawir. 2002. AlMunawir Arab-Indonesia. Surabaya: Pustaka Progresif.

Warson, Ahmad Munawir. 2010. Tuntunan Praktis Ziarah Kubur. Yogjakarta: Pustaka Pesantren.

\section{Jurnal Ilmiah}

Ahisma-Putra, Heddy Shri. November 2012, "Fenomenologi Agama: Pendekatan Fenomenologi untuk Memahami Agama”. dalam Jurnal Walisongo, Vol.20, No.2.

Faizin, Hamam. 2011. Mencium dan Nyunggi Al-Qur'an Upaya Pengembangan Kajian Al-Qur"an Melalui Living Qur"an, dalam Jurnal Jakarta: UIN Syarif Hidayatullah. Shuf, Vol.4, No.1.

Hamka. 2020. Jurnal Sosiologi Pengetahuan Telaah atas Pemikiran Karl Manhheim, Palu: IAIN Palu.

HS, Syihabuddin, A, Januarai-Juni 2013, "Tradisi Upacara Kematian Pada Masyarakat Nahdiyyin Dalam Tinjauan Agama Dan 
Adat" dalam Jurnal Al-Adyan, Vol.8, No.1.

Junaedi, Didi. 2015 Living Qur'an:

Sebuah Pendekatan Baru dalam

Kajian Al-Qur'an (Studi Kasus di

Pondok Pesanteren As-Siroj Al-

Hasan Desa Kalimukti Kec,

Pabedilan Kab, Cirebon, dalam

Jurnal Of Qur'an and Hadist

Studies Vol.4, No.2.

Khairul, Don Aziz. Lestari, Tri. 2020.

Jurnal Khazanah Keagamaan ;

Nilai-nilai Religius dan Tradisi

Ziarah Kubur Makam Syekh

Baribin di Desa Sikanco

Kecamatan Nusawungu Cilacap,

Makassar.

Mutamam, Hadi, Juli-Desember 2015,

"Tradisi Al-Qur'an Dalam

Fenomena Penafsiran" dalam

Jurnal Kebudayaan Islam,

Vol.13,No.2.

\section{Disertasi, Tesis dan Skripsi}

Fadlillah, Nilna. 2017. Resepsi

Terhadap Al-Qur'an Dalam

Riwayat Hadist. Yogjakarta: Ponpes Aji Masiswa Al Muhsin.

Faktu, Nur Rochman. 2018.

Pembacaan Surat Yasin dalam

Tradisi Tahlilan Kajian Living

Qur"an di Desa Palem Kecamatan

Campuradat, IAIN Tulungangung.

Hamid, Idham. 2017. Tradisi

Ma'abaca Yasin di Makam

Annangguru Maddappungan

Santri Pondok Pesantren Salafiyah

Parappe Kec. Campalagian Kab.

Polewali Mandar. Makassar: UIN

Alauddin Makassar.

Laelasari. 2020. Tradisi Membaca Suart

Yasin Tiga Kali Pada Ritual Rebo

Wekasan Di Kampung Sinagar

Desa Bojong, Kecamatan

Karangtengah, Kabupaten
Cianjur. Bandung: Uin Sunan Gunung Djati.

Majid, Ihsyanul. "Pembacaan Ayatayat Al-Qur'an dalam Tradisi Ziarah Kubur di Wogtagaleh (Studi Living Qur'an)”. Yogjakarta: UIN Sunan Kalijaga Yogjakarta.

W, Kusuma. 2015. Motivasi Masyarakat Palangkaraya Dalam Pelaksanaan Tradisi Menunggu Kuburan Dalam Tinjauan Hukum Islam.Palangkaraya: IAIN Palangkaraya.

Wahidi, Ridhoul. 2013. Hidup Akrab Dengan Al-Qur`an ; Kajian Living Qur'an dan Living Hadist Pada Masyarakat Indragiri Hilir Riau. Riau: Universitas Islam Indragiri.

Widayanti.2016 . Pembacaan surat Yasin dan Al-Mulk dalam penyelengaraan jenazah di Kecamatan Telaga Langsat Kabupaten Hulu Sulawesi Selatan. Banjarmasin: UIN Antasari Banjarmasin.

\section{Website, Internet dan Aplikasi}

Lidwa Pustaka i-Software-Kitab 9 Imam Hadist

http://kbbi.web.id/tradisi

http://id.m.wikipedia.org/wiki/Tradisi 